\title{
Neutralization with Simultaneously Separation of Aluminum Ions from Condensate Water through Cellulose Derivatives-Capillary Polypropylene Composite Membranes
}

\author{
ION MARIUS NAFLIU ${ }^{1}$, ALEXANDRA RALUCA GROSU (MIRON) ${ }^{1 *}$, HUSSAM NADUM ABDALRAHEEM AL-ANI², \\ PAUL CONSTANTIN ALBU ${ }^{3}$, GAVRIL GHEORGHIEVICI ${ }^{4,5}$, MIHAELA EMANUELA CRACIUN ${ }^{2 *}$ \\ 1Politehnica University of Bucharest, Faculty of Applied Chemistry and Material Science, Analytical Chemistry and Environmental \\ Engineering Department, 1-7 Gheorghe Polizu Str., 011061, Bucharest, Romania \\ IInstitute of Technology- Baghdad, Middle Technical University, Baghdad, Iraq \\ IIFIN Horia Hulubei, Radioisotopes and Radiation Metrology Department (DRMR), 30 Reactorului Str., 023465, Magurele, Romania \\ ${ }^{4}$ Carol Davila University of Medicine and Pharmacy, 8 Eroii Sanitari Str., 050474, Bucharest, Romania \\ ${ }^{5}$ Foisor Orthopaedics Clinical Hospital, 35-37 Ferdinand I Blvd., 030167, Bucharest, Romania
}

\begin{abstract}
Environmental problems that arise from acidic water containing aluminum generated from condensing thermal power plants can be suitably solved using membrane processes. In this paper, simultaneous neutralization with aluminum ion separation, from acidic waters containing aluminum traces, through permeation with polypropylene with inclusions of cellulose derivatives (PP / CellD)capillary composite membranes is approached. Cellulose derivatives considered are: acetylcellulose, carboxymethylcellulose, 2-hydroxyethyl cellulose, methyl 2 hydroxyethyl cellulose. The optimum working parameters for the best performance of composite membrane based on carboxymethylcellulose were determined: operating time and $\mathrm{pH}$ of the receiving phase. Simultaneously with the quantitative removal of the aluminum ions, it is obtained an almostneutral $\mathrm{pH}$ purified water, compatible with the natural waters in which itcan be dispersed.
\end{abstract}

Keywords: composite membranes, cellulosic derivatives, pertraction, aluminum separation

The unprecedented development of heat generation systems with condensing boilers, both for domestic heating and especially for public buildings (schools, hospitals, administrative spaces, etc) has generated an important environmental problem for the whole european area where are severe restrictions on the discharge of water into sewage [1-3].

Particularly, in Romania, the majority of condensing boilers are mural thermal plants, where the condensate in the exhaust pipe goes back to the condensation module, from which it is drained to drain (sewage) by means of the condensate drain siphon [2].

Although apparently the condensate $\mathrm{pH}$ of condensing boilers between 2 and 4 is not too aggressive, however, the range allowed by the European Directive for water spilled directly into the sewerage is limited [4]. Thus, the condensate of the thermal boiler evacuated to the sewerage must be within the required limits, meaning that the $\mathrm{pH}$ must be within the range of $\geq 6.5 ; \leq 8.5$ [5]. A further problem of the condensate is also the content of aluminum [6], or even copper ions [ 7].

Water treatment by membrane techniques has solved a large part of high effluent problems in small quantities and $\mathrm{pH}$ close to the limits allowed for discharge or containing metal ion traces [8-10].

In particular, cellulosic membranes are based on pure regenerated cellulose, native cellulose or derivatives thereof are extensively used [11-13].

Cellulose membranes have been produced for over a hundred years and have been among the first artificial membranes used in potable water production, desalination and food industry [12-15].

The properties of cellulose-based membranes are: biocompatibility, technical and economic accessibility, smoke, water, oxygen, other gases, water permeability, oil and hydrocarbs impermeability, excellent mechanical strength (flexibility, elasticity, contractility, rend and torsion) the possibility of thermal, chemical and radiation sterilization [16-20].

The uses of cellulose-based membranes are virtually limitless covering: water treatment from the energy industry, chemical and food industry, textiles and leather, agriculture and health, biotechnology and environmental protection [21-25].

The appearance of composite membranes (inert matrix - cellulose derivative) has helped to increase the selectivity and productivity of membranes by using more and more elaborate cellulose derivatives [26-28].

The concomitant regulation of the thermal power stations condensate $\mathrm{pH}$ and the removal of aluminum ions is the subject of this study, which addresses permeation through capillary polypropylene membranes with cellulose derivatives inserts.

\section{Experimental part}

Materials and methods

Materials and apparatus

$\mathrm{Al}_{2}\left(\mathrm{SO}_{4}\right)_{3} \cdot \mathrm{H}_{2} \mathrm{O}$, Sodium hydroxide, acetylcellulose, carboxymethylcellulose, 2-hydroxyethyl cellulose, methyl 2 hydroxyethyl cellulose, Sigma Aldrich, standard buffer solutions ( $p H=1.68 ; 4.01 ; 7.00 ; 10.01)$ from EUTECH Instruments.

Ultra pure water was obtained with a Millipore system.

The capillary polypropylene / cellulose derivatives (PP / $\mathrm{CD})$ composite membranes were obtained by impregnating the capillary membrane (PP) with the ionophore [31, 32].

The membrane module (scheme I) has a total area of 1 $\mathrm{m}^{2}$, phase shaking (source and receiving) being made with individual peristaltic pumps $[33,34]$.

\footnotetext{
*email: andra3005@yahoo.com; me.craciun@gmail.com
} 
The analyzes were performed with a CAMSPEC UV-VIS spectrometer and an atomic absorption spectrometer Atomic Absorption Sectrometer Perkin Elmer-AAnalyst 400 $[35,36]$, respectively.

\section{Procedures}

\section{Preparation of solutions}

Source phase (SP), synthetic aqueous solution, simulating condensate water $(\mathrm{pH} 2-4$, aluminum concentration $10^{-2}-10^{-4} \mathrm{Mol} / \mathrm{L}$ of $\mathrm{Al}_{2}\left(\mathrm{SO}_{4}\right)_{3}(342,131 \mathrm{~g} /$ $\mathrm{mol}$ ) was prepared by dissolving aluminum sulfate in the chosen $\mathrm{pH}$ solution.

Receiving phase (RP), the potassium hydroxide solution has a concentration of $10^{-4}$ to $1 \mathrm{Mol} / \mathrm{L}$ and was obtained by contacting the solid substance at $25^{\circ} \mathrm{C}$ in water.

\section{Membranes permeation}

The installation used for the permeation study provides a usable membrane surface area of $1 \mathrm{~m}^{2}$ [31, 32], the source phase solution volume is $3 \mathrm{~L}$, and the receiving phase is $300 \mathrm{~mL}$. The two phases are recirculated outside of the membranes (SP) and, respectively, through membranes (RP), by means of individual peristaltic pumps which can provide flow variations between 2 and $200 \mathrm{~mL} / \mathrm{s}$ (fig. 1).

Samples for analysis are taken at pre-established times using $1 \mathrm{~mL}$ syringes and analyzed on the UV-VISCAMSPEC spectrometer (for the receiving phase) and for validation of results at atomic absorption spectrometer (AAS PerkinElmer) [36-39].

The $\mathrm{pH}$ of the source phase was monitored with a Radelkis $\mathrm{pH} / \mathrm{mV}$ meter.

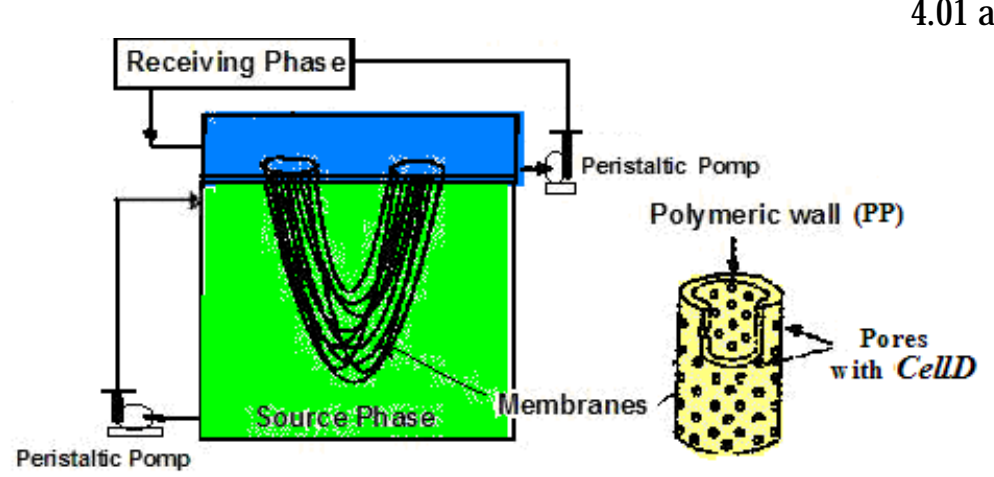

Fig. 1. The scheme of permeation installation

\section{Results and discussions}

Environmental issues that arise with the development of the energy industry are multiple [40-42]. Of course, large production units require special attention to both water pollution and air pollution or even soil [43-46]. However, small units producing domestic energy or for public buildings, which are mostly thermal condensing boilers, raise more and more problems. The $\mathrm{pH}$ of the condensate (2-4), but also the content of metal cations (aluminum, copper, tin, lead, ...) are aspects that must be taken into consideration for the discharge to the sewerage.

Both aspects presented, acid $\mathrm{pH}$ and metal ion content can be suitably solved using membranes and membrane processes [16-18, 31,32].

Practically, using the condensation water $(\mathrm{pH}=2-4$, containing $\mathrm{Al}^{\mid+}$) as the source phase, the $\mathrm{H}_{3} \mathrm{O}^{+}$ions and the aluminum ions are removed by the membranes if the receiving phase has a basic $\mathrm{pH}$ (fig. 2). The interaction of the hydrous and aluminum ions with the cellulose derivative is complex involving both the functional and free hydroxyl groups of the cellulose.

The ionophore from the composite membrane is a cellulose derivative: acetyl cellulose (AC), carboxymethyl cellulose (CMC), 2-hydroxyethyl cellulose (HEC), methyl 2 hydroxyethyl cellulose (MHEC) (fig. 3).

\section{Receiving phase the optimal flow rate determination}

In order to determine the optimal flow rate of the receiving phase, the source solution, with a volume of 10 times higher than the receiving phase, was recirculated at a constant rate of $100 \mathrm{~mL} / \mathrm{s}$ at standard $\mathrm{pH}$ of 1.68 and 4.01 and a concentration of $10^{-4} \mathrm{Mol} / \mathrm{L}$ of $\mathrm{Al}_{2}\left(\mathrm{SO}_{4}\right)_{3}$.

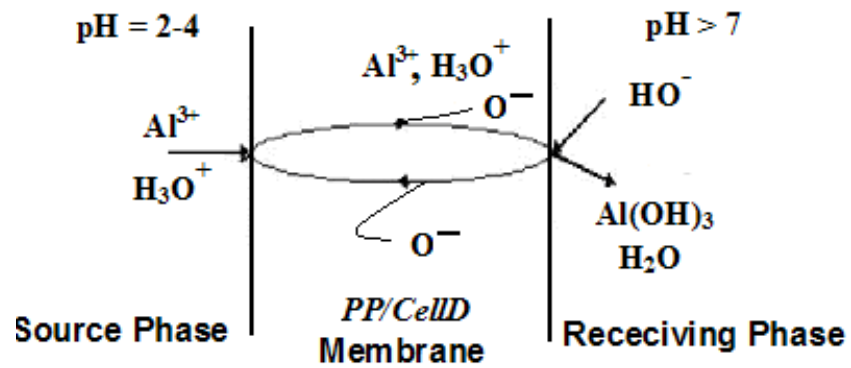

Fig. 2. Separation by pertraction with $\mathrm{pH}$ gradient: (a) $\mathrm{H}_{3} \mathrm{O}^{+}+$ chemical species of interest; $\mathrm{Al}^{3+}$ - competitive chemical species; $\mathrm{HO}^{-}$specific chemical reagent for the chemical species $\mathrm{Al}^{3+}$, -O- membrane ionophore, $\mathrm{Al}(\mathrm{OH})_{3}$ - insoluble compound

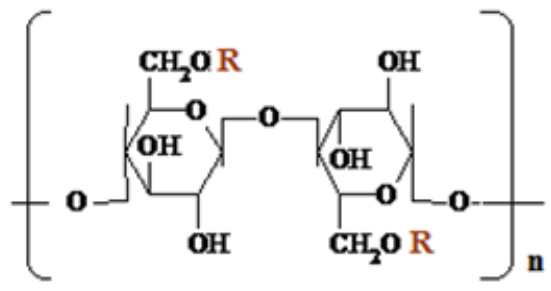

Fig. 3. Cellulose derivatives used as ionophores in the composite membrane PP/CellD: a) acetylcellulose (AC),

b) carboxymethylcellulose (CMC), c) 2 hydroxyethyl cellulose (HEC), d) methyl 2 hydroxyethyl cellulose (MHEC) 
The receiving phase flow $\left(Q_{R P}\right)$ is varied between 5 and $25 \mathrm{~L} / \mathrm{s}$ at $\mathrm{pH} 14$ in the receiving phase. The operating time is kept constant, $4 \mathrm{~h}$, for each working flow. The experimental study shows that the source phase neutralization occurs totally in the working time at receiving phases flows above $15 \mathrm{~mL} / \mathrm{s}$ (fig. 4 a-d)

The differences for the four types of membranes studied are both in the evolution of the source phase $\mathrm{pH}$ increase and in the limit $\mathrm{pH}$ reached at the maximum operating rate of the receiving phase. Thus, the efficiency of cellulosederived ionophore polypropylene membranes decreases in the order of: CMC> AC> MHEC > HEC.

These differences are correlated with the decrease in

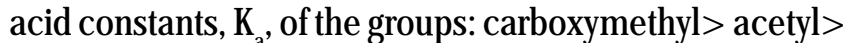
methylhydroxyethyl> hydroxyethyl.

$$
\begin{gathered}
\text { CellD-O-H+ } \mathrm{HOH} \rightleftarrows \text { CellD-O- }+\mathrm{H}_{3} \mathrm{O}^{+} \\
\boldsymbol{K}_{\boldsymbol{\alpha}}=\frac{\left[\text { CellID-O } \mathbf{O}^{-}\right]\left[\mathrm{H}_{3} \mathrm{O}^{+}\right]}{[\text {CellID-O-H }]}
\end{gathered}
$$

Determination of $\mathrm{pH}$ and optimal working time

In order to determine the $\mathrm{pH}$ and optimum working time, the polypropylene membrane installation with carboxymethylcellulose (PP / CMC) inserts was used, the source phase $\left(\mathrm{Al}^{3+} 10^{-3} \mathrm{M} ; \mathrm{pH}=2\right)$ with a flow rate of 200 $\mathrm{mL} / \mathrm{s}$ is contacted one at a time with receiving phases at a flow rate of $20 \mathrm{~mL} / \mathrm{s}$ and $\mathrm{pH}=7.00 ; 10.01 ; 12$ and 14.

Figure 5 shows significant differences in the evolution of aluminum ion concentration and $\mathrm{pH}$ in the source phase at $4 \mathrm{~h}$ operating time at the four $\mathrm{pH}$ values of the receiving phase.

In order to avoid solubilization of the cellulose derivative in the receiving phase, it is preferable to choose the $\mathrm{pH}=$ 12 , which is a good compromise between the need for neutralization and removal of the metal ion and the presumptive losses of the cellulose derivative if it would operate with the receiving phase in open system.

The operating time used in the previous experiments, 4 $h$, was chosen so that the condensation water treatment was done twice, with fresh receivig phases, within 8 hworking time for the workers.

In order to see if this working time is close to the optimum time of a treatment cycle without changing the receiving phase, has varied in the given experimental conditions: polypropylene membrane installation with carboxymethylcellulose inserts (PP / CMC), source phase $\left(\mathrm{Al}^{3+} 10^{-3} \mathrm{M}, \mathrm{pH}=2\right)$ with a flow rate of $200 \mathrm{~mL} / \mathrm{s}$ and a receiving phase with a flow rate of $20 \mathrm{~mL} / \mathrm{s}$ and a $p H$ of 12, operating time (fig. 6).
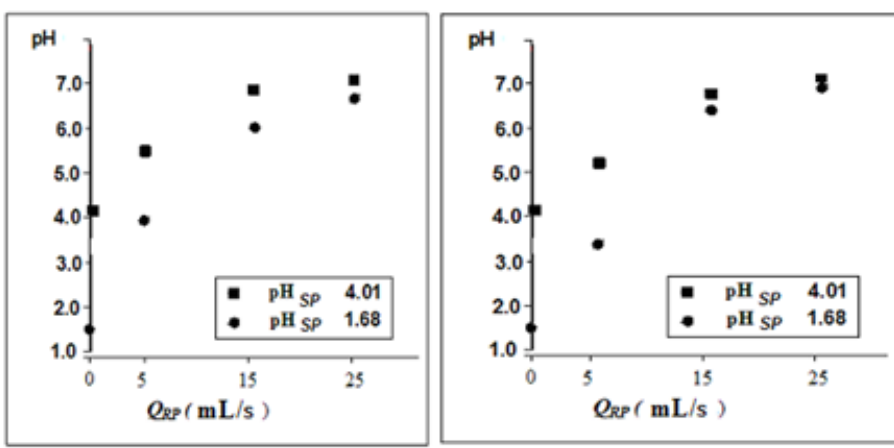

$a$
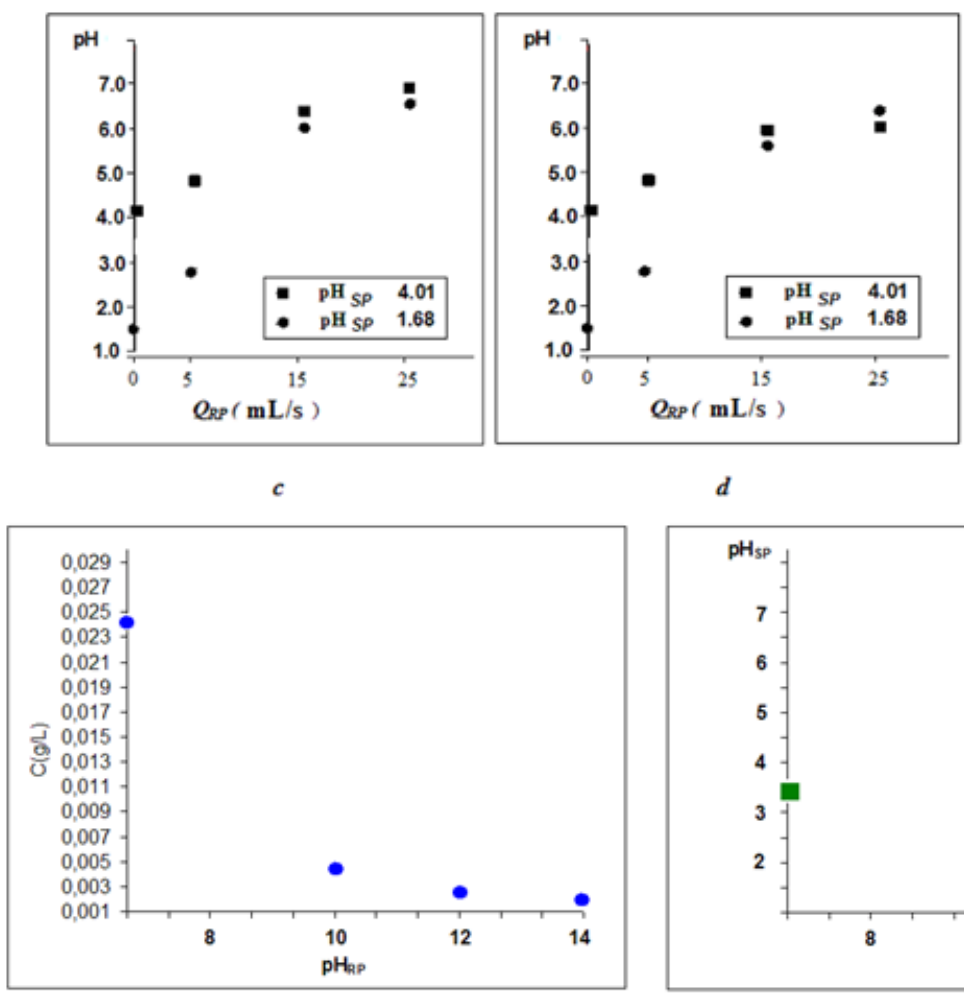

a

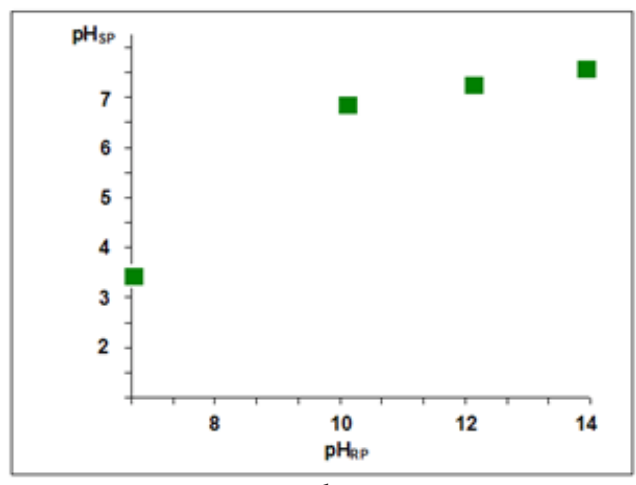

b
Fig. 4. Variation of performance parameters for neutralization and pertraction of aluminum according to the recirculation flow of the receiving phase with membrane based on: $a-C M C ; b-A C$; $c$ - MHEC; d-HEC
Fig. 5. Parameters performance variation for aluminum pertraction

(a) and neutralization $(b)$ depending on receining phase $\mathrm{pH}$ 


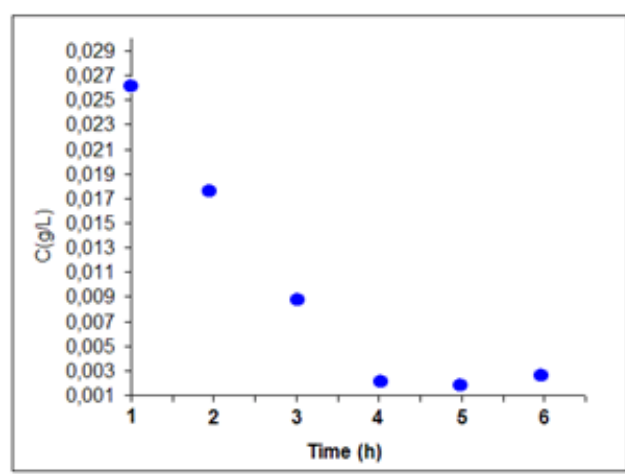

a

From the results shown in figures $6 a$ and $6 b$, the previously chosen working time, of $4 \mathrm{~h}$, is approaching to the optimum value of $4-5 \mathrm{~h}$, both in terms of aluminum ions elimination, especially neutralization.

It is noted that exceeding the $4 \mathrm{~h}$ interval results in a performance regression, especially in the case of neutralization, which suggests an inverse process controlled by dialysis due to lowering of the $\mathrm{pH}$ gradient.

Simultaneously with the quantitative removal of the aluminum ions, it is obtained an almost neutral $\mathrm{pH}$ purified water, compatible with the natural waters in which it can be discharged.

\section{Conclusions}

Environmental problems that arise from acidic water containing aluminum from condensing boilers can be adequately addressed using membrane processes.

The concomitant regulation of the thermal power stations condensate $\mathrm{pH}$ and the removal of aluminum ions is the subject of this study, which addresses permeation through capillary polypropylene membranes with cellulose derivatives inserts.

The cellulose derivative considered: acetyl cellulose (AC), carboxymethyl cellulose (CMC), 2-hydroxyethyl cellulose (HEC), methyl 2 hydroxyethyl cellulose (MHEC).

The efficiency of cellulose-derived ionophore polypropylene membranes decreases in the order: CMC> $\mathrm{AC}>\mathrm{MHEC}>\mathrm{HEC}$.

It is noted that exceeding the 4 hour interval results in a performance regression, especially neutralization, which suggests an inverse process controlled by dialysis due to lowering of the $\mathrm{pH}$ gradient.

\section{References}

1.*** | 9-2015- Normativ privind proiectarea, executia si exploatarea instalaiilor sanitare aferente cladirilor - publicat în Monitorul Oficial al Romaniei Partea I, nr. 830 bis din 06 noiembrie 2015

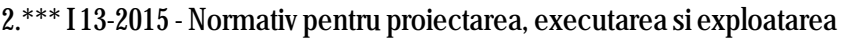
instalaiilor de incalzire centrala- publicat în Monitorul Oficial al României Partea I, nr. 897 bis din 02 decembrie 2015

3.*** HG 188/2002 pentru aprobarea unor norme privind conditile de descarcare în mediul acvatic a apelor uzate

4. ${ }^{* * *}$ Commission Directive 2000/60/EC of the European Parliament and of the Council establishing a framework for the Community action in the field of water policy

$5{ }^{* * *}$ Commission Directive 2009/90/EC on technical specifications for chemical analysis and monitoring of water status

6.*** UNI 7129-5:2015 - Impianti a gas per uso domestico e similare alimentati da rete di distribuzioni -Progettazione, installazione e mesa in servizio - Parte 5: Sistemi per lo scarico delle condense 7.*** HG 352/2005 privind modificarea si completarea HG 188/2002 pentru aprobarea unor norme privind condiiile de descarcare în mediul acvatic a apelor uzate -publicata în Monitorul Oficial al Romaniei Partea I, nr. 398 din 11 mai 2005
Fig. 6. Aluminium petraction variation (a) and neutralization (b), depending on the operating time

8.Van DER BRUGGEN, B., DAEMS, B., WILMS, D., VANDECASTEELE, C., Sep. Purif. Technol., 22-23, 2001, p. 519.

9.LEE, S.Y., KIM, B.N., HAN, J.H., CHANG, S.T., CHOI, Y.W., KIM, Y. H., MIN, J., J. Hazard. Mat., 182, 2010, p. 936.

10.TERESA, A., REIS, M., ONDINA DE FREITAS, M.F., ISMAEL, M.R.C., CARVALHO, J.M.R., J. Membr. Sci., 305, 2007, p. 313.

11.ROUSSEAU, R.W., Handbook of Separation Process Technology, Wiley, 1987.

12.ORTER, M.C., Handbook of Industrial Membrane Technology. Noyes Publication, Park Ridge, New Jersy, USA, 1990, p. 61.

13.SMOLDERS, C.A., in Ultrafiltration Membranes and Applications (A.R.Cooper, ed.) Pleum Press, New York, 1979, p. 161;

14.LOEB, S., SOURIRAJAN, S., Adv. Chem. Ser., 38, 1963, p. 117.

15.KESTING, R.E., J. Appl. Polym. Sci., 17, 1973, 1771.

16.KOENHEN, D.M., MULDER, M.H.V., SMOLDERS, C.A., J. Appl. Polym.

Sci., 22, 1977, p. 205.

17.STRATHMANN, S., Synthetic membranes and their preparation in Handbook of Industrial Membrane Technology, (M.C. Porter Ed.), 1990.

18.MULDER, M.H.V., Basic Principles of Membrane Technology, Kluwer Publishing Comp, Dorderecht, Netherlands, 1996

19.HWANG, S. KAMMERMEYER, K., Membrane in Separation, Wiley New York, 1975, p.125.

20.KESTING, R.E., Synthetic Polymeric Membranes, M.C. Graw Hill, New York, 1985.

21.LITEANU, C., RADULESCU, G., Bazele membranologiei, Ed. St. Enciclopedica, Bucharest., 1984.

22.BLATT, W.F., DAVID, A., MICHALES, A.S., NELSON, L., Membrane Science and Technology. Plenum Press, N,Y., 1970, p.47

23.LONSDALE, H.K., PODALL, H.E., Reverse Osmosis Membrane Research, Plenum Press, New York, 1970

24.AL ANI, H.N.A., CIMBRU, A.M., TANCZOS, S.K.., DIN, I.S., CUCIUREANU, A., NAFLIU, I.M., NECHIFOR, G., Rev. Chim. (Bucharest), 68, no. 3, 2017, p. 427.

25.SEGARCEANU, M., MIRON, A.R., TANCZOS, S.K., RIKABI, A.A.K.K., NAFLIU, I.M., VAIREANU, D.I., Mat. Plast, 55, no.2, 2018, p. 137.

26.NECHIFOR, G., ALBU, B.G., RATA, D., POPESCU, G., Rev. Chim. (Bucharest), 47, no. 3, 1996, p. 260.

27.RIKABI, A.A.K.K., CUCIUREANU, A., CHELU, M., MIRON, A.R., ORBECI, C., POPA, A.G., CRACIUN, M.E., Rev. Chim. (Bucharest), 66, no. 8, 2015, p. 1093.

28.DIN, I.S., CIMBRU, A.M., ANI, H.N.A.A., NAFLIU, I.M., TANCZOS, S.K., NECHIFOR, G., Rev. Chim. (Bucharest), 69, no. 5, 2018, p. 1084. 29.RIKABI, A.A.K.K., NECHIFOR, A.C., MOHAMMED, T. J., OPREA, O., MIRON, A.R., SEGARCEANU, M., VAIREANU, D.I., Rev. Chim. (Bucharest), 67, no. 8, 2016, p. 1489.

30.GHIMPUSAN, M., NECHIFOR, G., DIN, I.S., NECHIFOR, A.C., PASSERI, P., Mat. Plast., 53, no. 4, 2016, p. 578.

31.GHIMPUSAN, M., NECHIFOR, G., NECHIFOR, A.C., DIMA, S.O., PASSERI, P., J ournal of Environmental Management, 203, 2017, p. 811. 32.DIN, I.S., CIMBRU, A.M., RIKABI, A.A.K.K., TANCZOS, S.K., COTORCEA, S.T., NECHIFOR, G., Rev. Chim. (Bucharest), 69, no. 7, 2018, p. 1603. 
33.AL ANI, H.N.A., CIMBRU, A.M., TRISCA-RUSU, C., TANCZOS, S.K.., CUCIUREANU, A., NECHIFOR, A.C., Rev. Chim. (Bucharest), 68, no. 2, 2017, p. 203.

34.AL ANI, H.N.A., CIMBRU, A.M., DIN, I.S., TANCZOS, S.K., NAFLIU, I.M., CUCIUREANU, A., Mat. Plast., 54, no. 2., 2017, p. 353.

35.NAFLIU, I.M., AL ANI, H.N.A., GROSU (MIRON), A.R., TANCZOS, S.K., MAIOR, I., NECHIFOR, A.C.,Mat. Plast., 55, no. 4, 2018, p. 511

36.RIKABI, A.A.K.K., BALABAN (CHELU), M., HARABOR, I., ALBU, P.C., SEGARCEANU, M., NECHIFOR, G., Rev. Chim. (Bucharest), 67, no. 9, 2016, p. 1658.

37.COROBEA, C., DONESCU, D., RADITOIU, V., VOICU, S.I., NECHIFOR, G., Rev. Chim. (Bucharest), 57, no. 9, 2006, p. 981.

38.ZAHARIA, I., DIACONU, I., RUSE, E., NECHIFOR, G., Dig. J. of Nanomater. Bios., 7, no. 3, 2012, p. 1303.

39.LUCA, C., DUCA, AL., CRISAN , I. AL., Chimie analitica si analiza instrumentala, Editura Didactica si Pedagogica, Bucuresti, 1983

40.SZEP, R., MATEESCU, E., NECHIFOR, A. C., KERESZTESI, A., Environ. Sci. Pollut. Res., 24, no. 35, 2017, p. 27288.
41.ILIE, M., MARINESCU, F., SZEP, R., GHITA, G., DEAK, GY., ANGHEL, A.M., PETRESCU, A., URITESCU, B., Carpath. J. Earth. Env., 12, no. 2, 2017, p. 437.

42.SZEP, R., KERESZTES, R., KORODI, A., TONK, SZ.,NICULAE, A.G., BIRLOIU, A.M., Rev. Chim.(Bucharest), 67, no. 10, 2016, p. 1914.

43.SZEP, R., BODOR, Z., MIKLOSSY, I., NITA, I.A., OPREA, O.A., KERESZTESI, A., Sci. Total Environ., 647, 2019, p. 275.

44.KERESZTESI, A., PETRES, S., GHITA, G., DUMITRU, F.D., MONCEA, M.A., OZUNU, A., SZEP, R., Rev. Chim. (Bucharest), 69, no.1, 2018, p. 57. 45.SZZP, R., MATEESCU, E., NITA, A., BIRSAN, M., BODOR, Z., KERESZTESI, A., Atmos. Res., 214, 2018, p. 311. doi:10.1016/ j.atmosres.2018.08.009

46.BUNGAU, S., TIT, D.M., FODOR, K., CIOCA, G., AGOP, M., IOVAN, C., CSEPPENTO, D.C., BUMBU, A., BUSTEA, C., Sustainability, 2018, 10, 2788. doi:10.3390/su10082788

Manuscript received: 23.03 .2019 